\title{
DISINFECTION CAPACITY OF MOUTHWASHES USING AS ADMIX SOLUTION OF ALGINATE IMPRESSION
}

\author{
(KAPASITAS DISINFEKSI OBAT KUMUR DENGAN MENGGUNAKAN SOLUSI \\ CAMPURAN DARI CETAKAN ALGINAT)
}

\author{
Sumadhi Sastrodihardjo, Kholidina Imanda Harahap \\ Departemen Ilmu Material dan Teknologi Kedokteran Gigi \\ Fakultas Kedokteran Gigi, Universitas Sumatera Utara \\ Jl. Alumni No.2 Kampus USU Medan \\ E-mail: sanyrs@yahoo.com
}

\begin{abstract}
Immersion and spraying with disinfectant solution are the effective disinfection methods for alginate impression. However these methods causes dimensional changes on impression. Therefore mouthwash, which also has disinfectant function on microorganism can be used as mixing solution for alginate impression material. The aim of this study is to analyze antibacterial capacity of mouthwashes that used as admix solution for alginate impression. Samples was made from alginate impression material in tablet form with $15 \mathrm{~mm}$ diameter and $1 \mathrm{~mm}$ thickness. Total samples are 35,5 for admix with aquadest as control, chlorhexidine $0.1 \%$, povidon iodine, sodium fluoride $0.1 \% \mathrm{wv}$, respectively. Samples were put on incubated Staphylococcus aureus in petri dish and kept in incubator for 24 hours at $37^{\circ} \mathrm{C}$. Immersion was performed by dipping 15 samples of hygedent admix with aquadest into mouthwash liquids for 15 minutes. Inhibition zone was measured by using digital calliper. Statistic analysis was performed by using ANOVA one way and unpaired ttest. The admix with chlorhexidine $0.1 \%$ show the inhibition zone by $8.09 \mathrm{~mm}$, povidon iodine $0.52 \mathrm{~mm}$, and sodium fluoride $0.1 \%$ wv $2.91 \mathrm{~mm}$. By using immersion method they show $7.63 \mathrm{~mm}$ inhibition zone for chlorhexidine $0.1 \%$, $1.51 \mathrm{~mm}$ for povidon iodine, and $0.91 \mathrm{~mm}$ for sodium fluoride $0.1 \% \mathrm{wv}$. There are insignificant differences between admix and immerse with chlorhexidine $0.1 \%$ solution $(\mathrm{p}=0.25)$. It can be concluded that chlorhexidine mouthwash $0.1 \%$ has the equal antibacterial capacity when used for admix solution nor immerse the alginate impression.
\end{abstract}

Keywords: alginate impression, mouthwash, disinfection.

\begin{abstract}
Abstrak
Desinfeksi cetakan alginat efektif dilakukan dengan mempergunakan cairan desinfektan secara perendaman dan penyemprotan. Bagaimanapun kedua metode tersebut menyebabkan perubahan dimensi pada cetakan. Oleh karena itu obat kumur yang juga mempunyai fungsi desinfektan pada mikroorganisme dapat dipergunakan sebagai cairan pencampur bahan cetak alginat. Tujuan studi ini adalah untuk menganalisa kapasitas antibakteri obat kumur yang dipergunakan sebagai cairan pencampur cetakan alginat. Sampel dibuat dari bahan cetak alginat dalam bentuk tablet berdiameter $15 \mathrm{~mm}$ dan ketebalan $1 \mathrm{~mm}$. Besar sampel 35, masing-masing 5 untuk campuran dengan akuades sebagai control, klorheksidin $0,1 \%$, povidon iodin, sodium fluorid $0,1 \%$. Sampel diletakan pada cawan petri yang telah diinkubasi dengan Stafilokokus aureus dan disimpan dalam inkubator untuk 24 jam pada temperatur $37^{\circ} \mathrm{C}$. Perendaman dilakukan dengan mencelupkan 15 sampel hygedent campur akuades dalam cairan obat kumur selama 15 menit. Zona hambatan ditentukan dengan mempergunakan caliper digital. Analisa statistik dilakukan dengan mempergunakan ANOVA satu arah dan t-test tidak berpasangan. Pencampuran dengan klorheksidin 0,1\% memperlihatkan zona hambatan sebesar $8,09 \mathrm{~mm}$, povidon iodin $0,52 \mathrm{~mm}$ dan sodium fluorid $0,1 \% \mathrm{wv} 2,91 \mathrm{~mm}$. Dengan metode perendaman terlihat zona hambatan sebesar 7,63mm pada klorheksidin $0,1 \%, 1,51 \mathrm{~mm}$ pada povidon iodin dan $0,91 \mathrm{~mm}$ pada sodium fluorid $0.1 \%$. Terlihat perbedaan yang tidak signifikan diantara pencampuran dan perendaman dengan klorheksidin $0,1 \%(\mathrm{p}=0.25)$. Dapat disimpulkan bahwa obat kumur klorheksidin $0,1 \%$ mempunyai kapasitas antibakteri yang sama baik dipergunakan sebagai cairan pencampur maupun dengan perendaman cetakan alginat.
\end{abstract}

Kata kunci: cetakan alginat, obat kumur, desinfeksi. 


\section{INTRODUCTION}

It has been known that impressions may transmit bacteria or virus from saliva and blood of the patient's oral cavity to the operators. Washing the impression does not eliminate all of the microorganism or virus. This cross contamination should be avoid by disinfected the impressions immediately after their removal from the oral cavity. Commonly disinfection agents used are chlorine compound, iodofor, glutaraldehide and phenol. ${ }^{(1,2,3)}$ There are several ways in which the impression can be disinfected including spray and immersion disinfection methods. Unfortunately these methods can affect the accuracy of alginate impression and other properties of impression materials. ${ }^{4,5,6}$

The manipulation of alginate impression need liquid to be mixed. Usually tap water is used as admix solution. There were several studies about the admix of disinfectant to alginate impression materials and their effects to the properties of impression materials. Amalan et al. evaluated the proper- ties of irreversible hydrocolloid impression materials mixed with disinfectant liquids such as $\mathrm{pH}$ changes during setting, measurement of gelation time, flow, gel strength, permanent deformation and surface detail reproduction. Dorner et al. investigated surface roughness and dimensional accuracy of dental stone cast after disinfection the impression. Other researchers did also show the effect of disinfection on properties of impression material. ${ }^{7,8,9}$ The purpose of this study is to evaluate the antibacterial activities of mouthwashes used as admix solution to alginate impression material.

\section{MATERIALS AND METHODS}

Table 1 gives the details of the materials used in this paper. Three mouthwashes, one alginate impression material and Cultured staphylococcus aureus were used in this study.

\begin{tabular}{lllcc}
\hline No & \multicolumn{1}{c}{ Materials } & \multicolumn{1}{c}{ Type } & \multicolumn{1}{c}{ Product } & $\begin{array}{c}\text { Batch/Lot } \\
\text { number }\end{array}$ \\
\hline 1 & Impression mat. & $\begin{array}{l}\text { Irreversible hydrocolloid alginate, } \\
\text { regular set }\end{array}$ & $\begin{array}{c}\text { Hygedent, Hygedent, } \\
\text { Inc }\end{array}$ & 1406051 \\
\hline 2 & Mouthwash & Chlorhexidine Gluconate 0.1\% & Minosep, Indonesia & 41231 \\
\hline 3 & Mouthwash & Povidon Iodine 1\% & Betadine, Indonesia & C315098 \\
\hline 4 & Mouthwash & Sodium Fluoride 0.1\% wv & Total Care, Indonesia & $142 / 3113$ \\
\hline 5 & Bacteria & Staphylococcus Aureus & $\begin{array}{l}\text { Inoculated from } \\
\text { stomatitis lesion }\end{array}$ & \\
\hline 6 & Aquadestilata & H2O & $\begin{array}{c}\text { Local } \\
\text { Indonesia }\end{array}$ & \\
\hline
\end{tabular}

Table 1. Impression material, mouthwashes and bacteria used

Thirty five samples of alginate impression materials were built in tablet shape with $15 \mathrm{~mm}$ diameter and $1 \mathrm{~mm}$ thickness by using rubber ring. Alginate impression materials were mixed with aquadestilata, Chlorhexidine Gluconate $0.1 \%$, Povidon Iodine $1 \%$ and Sodium Fluoride $0.1 \%$ wv mouthwashes. P/L ratio was $5 \mathrm{~g}$ powder and $11.5 \mathrm{ml} \mathrm{li-}$ quid following the manufacturer instruction. Immersion method was performed by dipping the samples of hygedent admix with aquadest into mouthwashes for 15 minutes.
Staphylococcus aureus bacteria was incubated on Nutrient agar in petri dish for three days in incubator at $37^{\circ} \mathrm{C}$. The admix samples were put on incubated Staphylococcus aureus in petri dish and kept in incubator for 24 hours at $37^{\circ} \mathrm{C}$. The immersed samples were put also on Staphylococcus aureus layer by the same way as admix samples. Inhibition zone as transparent area of Staphylococcus aureus was measured by using digital calliper. Statistic analysis was performed by using ANOVA one way with the mean difference is significant at the 0.05 level. 


\section{RESULT}

The transparent area around the samples as the inhibition zone of Staphylococcus aureus after treatment shown in Figure 1.

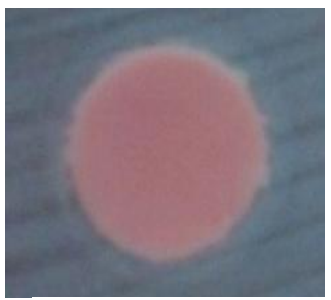

a

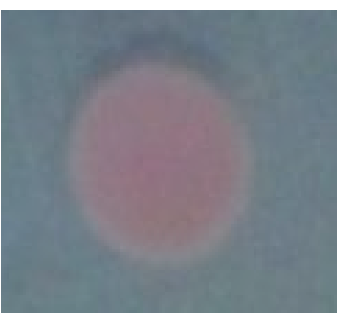

c

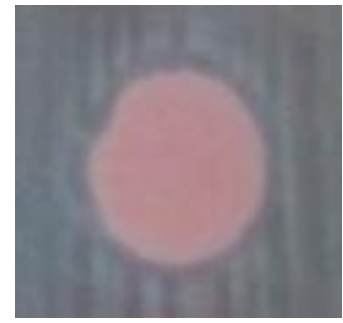

e

Figure 1. Inhibition zone of staphylococcus aureus bacteria around the samples
a. Hygedent + Aquadestilata (control)
b. Hygedent + Minosep
c. Hygedent + Betadine
d. Hygedent + Aquadestilata immersed in Menosep
e. Hygedent + Aquadestilata immersed in Betadine

Hygedent impression material admix with aquadestilata show have no transparent area of Staphylococcus aureus layer or inhibition zone. Hygedent admix with minocep and hygedent admix with aquadestilata immersed in minocep show wide inhibition zone. But hygedent admix with betadine nor hygedent admix aquadestilata immersed in betadine show a narrower inhibition zone as well as by using total care mouthwash both for admix nor immerse procedure.

The measurements of inhibition zone shown in Table 2.
Table 2. Inhibition zone measurements of several treatment on impression material

\begin{tabular}{|c|c|c|c|c|c|}
\hline No & Treatment & $\begin{array}{c}\text { Inhibition } \\
\text { zone } \\
\text { Mean } \pm \\
\text { SD }(\mathbf{m m}) \\
\text { Hygedent } \\
\text { Admix } \\
\text { with }\end{array}$ & $\mathbf{n}$ & $\begin{array}{c}\text { Inhibition } \\
\text { zone } \\
\text { Mean } \pm \\
\text { SD }(\mathbf{m m}) \\
\text { Hygedent } \\
\text { immersed } \\
\text { in }\end{array}$ & $\mathbf{n}$ \\
\hline 1 & $\begin{array}{l}\text { Aquadestilata } \\
\text { (Control) }\end{array}$ & $\begin{array}{c}0.00 \pm \\
0.00\end{array}$ & 5 & & \\
\hline 2 & Minosep & $\begin{array}{c}8.09 \pm \\
0.77\end{array}$ & 5 & $\begin{array}{c}7.63 \pm \\
1.35\end{array}$ & 5 \\
\hline 3 & Betadine & $\begin{array}{c}0.52 \pm \\
0.14\end{array}$ & 5 & $\begin{array}{c}1.51 \pm \\
0.54\end{array}$ & 5 \\
\hline 4 & Total Care & $\begin{array}{c}2.91 \pm \\
0.18\end{array}$ & 5 & $\begin{array}{c}0.91 \pm \\
0.09\end{array}$ & 5 \\
\hline
\end{tabular}

Hygedent impression material admix with Minosep show $8.09 \pm 0.77 \mathrm{~mm}$, and $0.52 \pm 0.14 \mathrm{~mm}$ for admix with Betadine and $2.91 \pm 0.18 \mathrm{~mm}$ for admix with Total Care mouthwashes. By using ANOVA one way all of this treatments show a significant differences $(\mathrm{p}=0.00)$.

By using immersion methods with Minosep, Betadine and Total Care mouthwashes the result show inhibition zone as large as $7.63 \pm 1.35 \mathrm{~mm}, 1.51 \pm$ $0.54 \mathrm{~mm}$ and $0.91 \pm 0.09 \mathrm{~mm}$, respectively. Compare between admix method with immersion method there are insignificant differences for Minosep solution $(\mathrm{p}=0.25)$ but significant with Betadine solution $(\mathrm{p}=0.019)$ or Total Care $(\mathrm{p}=0.00)$ solution mouthwashes.

\section{DISCUSSION}

Admix with mouthwash show a significant inhibition zone differences on incubated Staphylococcus aureus. Among these three mouthwashes Minosep has a very high capacity as an antibacteria followed by Total Care. Meanwhile, Betadine mouthwash has a very low effect.

There are insignificant differences of inhibition zone between admix methods and immersion methods of Minosep which show a similar antibacterial effects. This study show that Minosep has the equal antibacterial capacity when used for admix solution or immerse the alginate impression into.

The result of this investigation coincidence with the result of investigation of Touyz et al. that chlorhexidine is an effective alginate disinfectant, when it is used as the liquid for alginate preparation and post-setting disinfection solution. ${ }^{10}$ Wang J. et al also noted that Chlorhexidine self-disinfecting ireversible hydrocolloid impression material can exhi- 
bit varying degrees of antibacterial activity. ${ }^{6}$ Correia-Sousa also declared that hypochlorite disinfection is an efficient disinfection method for alginate impressions. ${ }^{11}$

Wang $\mathbf{J}$ et al show that Chlorhexidine self disinfecting irreversible hydrocolloid impression material did not influence the three-dimensional accuracy of impression. ${ }^{6}$ The immersion and spray methods have a side effect as swelling on the impres-

\section{REFERENCE}

1. Anusavice KJ, Shen C, Rawls HR. Phillips' science of dental materials. $12^{\text {th }}$ ed., St Louis: Saunders, $2013 ; 171-5$

2. Haralur SB, Al Dowah OS, Gana NS, Al-Hytham A. Effect of alginate chemical disinfection on bacterial count over gypsum cast. J Adv Prothodont 2012; 4: 84-8

3. Bustos J, Herrera R, Gonzalez U, Martinez A, Catalan A. Effect of immersion disinfection with $0.5 \%$ sodium hypochlorite and $2 \%$ glutaraldehyde on alginate and silicone: microbiology and SEM study. Int J Odontostomat 2010; 4(2): 169-77

4. Hiraguchi H, Kaketani M, Hirose H, Yoneyama T. The influence of storing alginate impression sprayed with disinfectant on dimensional accuracy and deformation of maxillary edentulous stone model. Dent Mater J 2010; 29(3): 309-15

5. Panza LHV, Porto VC, Salvador MCG, Silva Rosa OP. Evaluation of dimensional stability of impression materials immersed in disinfectant solutions using a metal tray. Revista OdontoCiencia - Fac Odonto/PUCRS 2006; 21(53): 261-5

6. Wang J; Wan Q; Chao Y; Chen Y. A self-disinfecting irreversible hydrocolloid impression material mixed with chlorhexidine solution. Angle Orthod, 2007; 77(5): 894-900. sion material due to its imbibition properties of hydrocolloids impression material. The admix methods have no imbibition process during the procedure of impression disinfection avoid a possibility of dimensional change on the impression occur. This phenomenon need to be examinated furthermore.

7. Amalan A, Ginjupalli K, Upadhya N. Evaluation of properties of irreversible hydrocolloid impression materials mixed with disinfectant liquids. Dent Res J (Isfahan) 2013; 10(1): 65-73

8. Dorner AR, Ferraz da Silva JM, Uemura ES, Borges AL, Fernandes Junior VB, Yamamoto ETC. Effect of disinfection of irreversible hydrocolloid impression materials with $1 \%$ sodium hypochlorite on surface roughness and dimensional accuracy of dental stone cast. Eur J Gen Dent 2014;3:113-9

9. Dulaimi SF, Al Wahab ZN. The effect of disinfectants on the surface quality of irreversible hydrocolloid impression material and gypsum cast. Iraqi Nat J Nursing Spec 2012; 25(1); 95-100

10. Touyz LZG, Rosen M. Disinfection of alginate impression material using disinfectants as mixing and soak solutions. J Dent 1991; 19(4): 255-7

11. Correia-Sousa J, Tabaio AM,, Silva A, Pereira T, Sampaio-Maia B, Vasconcelos M. The effect of water and sodium hypochlorite disinfection on alginate impressions. Rev Por Estomatol Med Dent Cir Maxilofac 2013;54(1):8-12 